\title{
BELGRADE MARKET AS A PART OF THE GLOBAL FINANCIAL MARKET
}

\author{
Nataša Simić, ${ }^{1}$ Vesna Petrović ${ }^{2}$, Dušan Aničic ${ }^{3}$ \\ ${ }^{1,2}$ Faculty of entreneurship and real estate management, Union University-Nikola Tesla, Belgrade, \\ Serbia \\ ${ }^{3}$ DSN Konsalting, Belgrade, Serbia \\ anicic.dusan@yahoo.com
}

\section{Professional Paper \\ doi:10.5937/jouproman6-15619}

\begin{abstract}
Belgrade market has been operating since 1989 under the name of Yugoslav capital market, which changed its name to Belgrade market in 1992. The purpose and the idea which governs our financial authorities and the market participants is a more active involvement of the market in the operations of the global financial market.
\end{abstract}

Keywords: Belgrade market, financial market, participants on the financial market

\section{Introduction}

Market operations imply a stipulated and defined set of rules of behavior of participants on the market. The rules of behavior operation and work of all global markets have been clearly defined and established. It is clear that market operations could not function without unification of these procedures. These principles have been globally established and the participants have the obligation to follow them as such. Institutional organization of markets varies across the world, but the approach and the operational procedure is the same or similar.

\section{Markets as organized financial markets and their operation}

Markets represent organized trading locations where the representatives of the sellers and the buyers perform the sale and purchase process, as a rule, in form of an auction. Their basic function is provision of continuous market, i.e. the possibility to purchase and sell effects per prices which slightly differ from the previously agreed prices. Functioning of markets enables several important effects:

- markets provide continuous market, which means liquidity for quoted securities. The possibility of fast sale of quoted securities provides the investors with the possibility to keep free assets within relatively productive placements without endangering their liquidity. This affects increase of general employment of assets in the economy and the efficiency of their use;

- markets lower the price of capital acquirement for companies;

- markets

constantly

examine the value of securities and their issuers:

- markets provide relatively higher stability of prices of securities;

- on markets, trade of shares also includes trade of ownership and managerial rights over a corporation, through purchase of a controlling set of shares:

- by enabling sale and purchase of securities, the markets enable migration of capital into more prosperous branches and companies; 
- the buyers and sellers are anonymous on the market because trade is performed by representatives on their behalf. Due to the above, the buyers and sellers are exclusively guided by the motives of profitability and efficiency;

- by securing liquidity, the markets facilitate absorption of new effects emissions, which encourages new investments and incites developmental process in the economy.

OTC market represents all sale and purchase activities related to securities which are not performed on the market. OTC represents a manner of trade and it includes hundreds of broker-dealer companies which deal with sale and purchase of securities outside of the market, as well as some securities which are quoted on the market. OTC is an interdealer market with wholesale and retail trade.

Besides primary and secondary, "third" and "fourth" market are also mentioned in the USA. Both actually represent isolated segments of the secondary market. Development of the third and the fourth market is a consequence of the growth of significance of institutional investors and large, socalled "block transactions" with absence of discounts for commissions for large block trades, which made their executions on markets too expensive. Both markets represent direct competition to markets. Transactions of the third market include trade with shares which are quoted on the markets, and transactions of the fourth market represent direct transfers of large share lots among institutional investors without brokerage.

Automatisation and computerization of the clearing process has a special significance for increase of functioning of the financial market and it is executed in two stages: the first, sending reports on performed transactions and their comparison in the so-called clearing corporations, and the second, final settlement (balancing).

\section{Sources of financial information}

Active management of securities portfolio implies continuous adaptation of the portfolio structure with new market circumstances, in order to satisfy as much as possible the set investor's preferences (Aničić et all. 2017, p 45-54). Constant sale and purchase of securities from the portfolio implies that some securities have qualified for, and the other have lost the characteristics required for them to be a constituent part of the portfolio. The decision on sale and purchase of securities is based on investment expectations of the portfolio manager, and the investment expectations are based on financial information on performances of securities, as well as other information that can affect them. The all-encompassing and understandable information represents a "basic means" in work of all investors, and intelligent interpretation, evaluation and analysis of the information represents the basis for investment decisions.

\section{Financial publications}

Financial publications provide basic financial information to portfolio managers, and they directly or indirectly deal with financial markets and represent a very important source of information on the occasion of reaching investment decisions.

Important financial information can be obtained from daily newspaper which, beside the current reports on global political and economic conditions which have a significant effect on investor's mood, also publishes special business sections in their issues. 
These sections, among other things, contained detailed reports on market movement of securities. Specialized daily newspaper (Wall Street Journal and others) also provide global and national financial news reports on certain economic branches or companies, as well as professional opinions on future events on the financial markets and economy in general. Besides the above-mentioned, periodicals (weekly, monthly, etc.), for example Business Week, Forbes, Fortune and others, which process statistical data and tables from financial and commodity market are also important.

The state, through its authorities and organizations (Trade Secretariat, National Bureau of Economic Research, and other), is an important issuer of business information and it issues periodical overviews and prognosis of future movement on the capital market. The globally known issues are monthly Survey of Current Business, Long - Term Economic growth, Economic Indicators, Business Conditions Digest and others.

However, more complete systematization of business information is provided by daily, weekly and monthly publications and specialized consulting agencies for provision of investment information such as Standard and Poors Corporation, Moodys Investors Services Inc, The Value Line Investment Survey and others. They, as a rule, contain basic analyses in annual issues and more frequent actual amendments - quarterly, monthly or weekly. The globally known publications are Stock Guide and Bond Guide, which are issued once in a month and include information about more than 12000 different securities - shares of corporations and investment companies, domestic and foreign bonds, and a combined final annual Stock and Bond Guide is published at the end of the year.
Large broker-dealer companies issue their own publications, especially those which have their own research departments. Their publications most frequently take the form of fact books or recitals.

A large number of professional magazines which are specialized in financial problems, significant number of computer databases, overviews of certain industrial branches and companies and others should also be pointed out to as significant sources of financial information.

\section{Market indicators}

Market indicators should provide a clearer image of directions of the total market movement, as well as basis and frame of movement of individual share prices in certain market segments. Two basic sizes which can provide significant information for identification of market indicators are prices and quantities the market movement of which provides basis for making conclusions on movement of prices of the observed securities. Basically, market indicators are divided into price indicators, quantity indicators and other indicators.

The price indicators include the following: ratio between increasing prices and decreasing prices, ratio between the new highest prices and the new lowest prices and movement of share prices.

The basic idea in terms of ratio between increasing and decreasing prices is to establish the movement of the prices of the largest portion of shares on the market. Comparison of the number of decreasing share prices provides the image of presence of the general movement of share prices on the market, i.e. provides the breadth of market. 
As a rule, in order to obtain the ratio of increasing and decreasing share prices, daily net difference in the number of shares with increasing and decreasing prices is calculated. This net difference is added to net difference from the last market day and it forms cumulative indicator of market movement. This indicator, as a rule, moves proportionately to the movement of stock indices, but it provides a more realistic image of market movement in comparison with the indices.

The relationship between the new highest and the new lowest prices is a complementary indicator in establishment of market movement. The higher number of shares which are at their price maximum, as a rule, is characterized by growing market, i.e. general growth of the market prices and vice versa, a higher number of the shares which are at their price minimum, as a rule, are characterized by general decrease of prices on the market, i.e. decreasing market.

Price movement of the most active shares can point out to future movement of the whole market. The information about 20 shares which were the most active shares during the previous week is published in the USA weekly. These shares, although they frequently represent a small part of the total number of shares, represent a significant segment of the total turnover. The indicator of the most active shares is structured so that it reflects changes of prices for the most active shares and it indicates the changes on the total market.

The indicators of quantity rely on the understanding which implies that the changes in the scope of the turnover represent a prerequisite for all price changes. The basic rules are that the turnover scope in a growing market is higher if the prices are on the increase, and it is lower if the prices decrease and vice versa, on a decreasing market increases with a faster decrease of prices and decreases with growth of prices. Also, the scope of turnover, as a rule, decreases before significant market changes and increases before market recovery. The known indicators in this group are the quantity indicators which include a relationship between NYSE and AMEX turnover, the indicator of the short-term sale and the indicator of trade with odd share lots.

Other market indicators are also numerous, and the most frequently used ones are the indicators of activity of investment companies, trust indicators and movement indicators on the investor's accounts with their broker-dealer companies.

The capital owned by the investment companies in the USA is the largest among institutional investors on the financial market. Pursuant to that, the movement of the capital of investment companies significantly affects complete market movement, so the monitoring of that movement can provide significant information on future movement on the financial market. If the indicator of the activity of investment companies is higher, that means that there is a potentially significant purchase power ready for investment and it can be expected that its activation will cause market increase in the near future, and vice versa, low indicator values imply that the investment companies have already invested almost all available funds and that they do not have additional purchase power, which implies recent achievement of market peak and market decrease which will follow. 


\section{Market indices}

Market indices which in most countries represent a very popular manner of presentation of market movements represent a special and the most frequently used group of market indicators. Market indices should, through their price movement, provide answer to the basic question: "how the financial market moves?". The indices may be compiled so that they represent financial market as a whole or its individual segments, such as industrial areas or individual types of securities.

Basically, market indices can be pondered or non-pondered averages of the value of securities and the indices which are calculates as the ratio of the observed and the basic pondered averages of the selected securities. The best known market indices include Dow Jones indices system, value line composite average, Standard and Pur 500 composite average of shares and other.

Market indices can be divided into three groups pursuant to their origin. The first group represents the indices which are made by specialized institutions which subjectively choose which securities will be included in the indices structure. The second group represents indices which are also prepared by specialized institutions, but with use of objective criteria for selection of securities which are included in the index. The third group represents indices calculated by the markets, including all observed securities which are traded on the market in the observed period.

Market indices, especially those which approximate movement of the financial market as a whole, ${ }^{8}$ have a

${ }^{8}$ Significant interdependence between movement of indices in developed western economies and their infuence on movement of indices in our region can significant role in portfolio management. They are important for identification of $B$ quotient as a measure of exposure of individual securities and portfolios to systematic (market) risk. Comparison of B quotients of individual securities and portfolios and appropriate achieved income rates may provide conclusions about underestimate or overestimate of the above-mentioned, and further about the need to correct the portfolio of the structure as a constituent part of the active portfolio management policy. Market indices are important for construction of portfolios that are supposed to have a structure which will secure their movement in full harmony with the complete market movement. Market indices represent benchmarks based on which the efficiency of the management of investments into securities is established, i.e. they show what result would be achieved without active portfolio management.

The aim of the game is "to beat" the market index, i.e. the market ("beat the street") and prove superiority and the efficiency of active portfolio management.

\section{Belgrade a market in the view of global financial market}

Yugoslav capital market was established with the adoption of the Money and Capital Market Act in 1989 and it changed its name into Belgrade market in 1992.

Belgrade market has become an associate of the global market association - WSE, as well as the European market association FESE, and it is also a member of the Federation of European and Asian Stock Exchanges - FEAS.

be observed in the example of real estate market crisis in the USA in the second half of 2007, which more or less transferred to indices in our region. 
Belgrade market also organizes and hosts international conferences each year and the topics of the conferences are dedicated to the newest movements on the market capital, corporate management, stock exchange analyses and indicators.

The subjects on the Belgrade market are: stock owners, those who possess securities (shareholders and others) and wish to sell them, investors, buyers of securities (legal or natural entities), brokers, persons who sell and purchase securities pursuant to orders.

Trade with company shares which have been obtained "without compensation", during the previous privatizations is especially actual. The objective of the leading index of the Belgrade market, whose full name is Index of the most liquid Serbian stocks, is to present the movement of the prices of stock traded in the method of continuous trading and which fulfilled the criteria for inclusion into index basket as precisely as possible. Continuous trading is performed by means of automatic pairing of the sale and purchase warrants for individual stocks per certain

BELEX15 index is calculated and published since October 2005, on each business day of the Market, in real time, since the moment when the condition for its calculation and publication has been fulfilled until formation of prices at closure, as published on the website of the Belgrade market.

The other index which shows movement on Serbian capital market is "General index of Belgrade stock market BELEXlajn', which replaced the first stock index of the Belgrade stock market, BELEXfm.

The basic difference between these two indicators is that BELEXlajn represents price movement for the representative sample of securities which are being traded, in comparison with the methodology of BELEXfm, which provided presentation of price movement of all securities which concluded at least one transaction on a specific day. BELEXfm was calculated from December $13^{\text {th }}, 2004$, until April $30^{\text {th }}, 2007$, when it was replaced with BELEXlajn index.

There is another "Serbian' index BELEX sentiment, which presents expectations of market participants in the following period, i.e. the next month. The values of BELEX sentiment for February was at historical minimum, which indicates that participants on the capital market $d$ not hope that the stock prices and value of the Belgrade market index will recover any time soon.

This justifies the note that the market of the Belgrade stock market thereby confirms integration into total economicpolitical events in the country. It should be borne in mind that there is instability on global financial markets and stock markets due to deteriorated economic activities. (Aničić et all, 2017, p 36-44).

\section{Conclusion}

Belgrade stock market is a capital market with long tradition. It represents a market in dynamic development, and especially in the transition process in which the economy of the Republic of Serbia is.

Insufficient growth of industrial production and employment, indebtedness of the real sector and population, represent significant challenges with which national economy of our country meets. However, investment funds are active again, which positively reflects on turnover on the Belgrade stock market. 
This indicates positive movement in relation to those which were present in Serbia during earlier years.

\section{Literature:}

1. Aničić, J., Simić, N., Petrović, V, Aničić, D., (2017) Financial aspect of current assets management in Sebian economy, Journal of Process Management - New Technologies International, Volume 5(2), 36-44.

2. Aničić, J., Aničić, D., Majstorović, A., (2017) Accounting and financial reports in the function of corporate governance, Journal of Process Management - New Technologies
International, Volume 5(2), 45- 54.

3. Dugalić, V., Stimac, S., (2005) Osnove berzanskog poslovanja, Beograd, Stubovi kulture

4. Kohn, M., (2004) Financial institutions and markets, New York, Oxford University Press, Inc

5. Vasiljević, B., (2006) Finansijska tržišta, peto izdanje, Beograd, Zavet

6. Vukotić, S. (1997). Kodeks ponasanja aktera na berzi, Ekonomski vidici, No 4, Beograd.

7. Vukotić, S. (1999). Organizacija berzanskog poslovanja, Ekonomski vidici, No 4, Beograd.

8. www.belex.rs 